\begin{tabular}{|c|c|c|}
\hline FALOAK & Jurnal Penelitian Kehutanan Faloak (2021) 5(1), 62-73 & \\
\hline & JURNAL PENELITIAN KEHUTANAN FALOAK & ALOAK \\
\hline $1 /=$ & $\begin{array}{l}\text { Akreditasi KEMENRISTEKDIKTI: 10/E/KPT/2019 } \\
\text { http://ejournal.forda-mof.org/ejournal-litbang/index.php/JPKF }\end{array}$ & $\begin{array}{l}\text { e-ISSN } 25795805 \\
\text { p-ISSN } 2620617 \mathrm{X}\end{array}$ \\
\hline
\end{tabular}

\title{
PENGARUH SUHU DAN KONSENTRASI ASAM FOSFAT (H3PO4) TERHADAP KUALITAS ARANG AKTIF CABANG BAMBU DURI (Bambusa blumeana BI. Ex. Schult. F.)
(Effect of Temperature and Concentration of Phosphoric Acid $\left(\mathrm{H}_{3} \mathrm{PO}_{4}\right)$ on the Quality of Activated Charcoal of Bambusa blumeana Branch)

\author{
Turmiya Fathal Adawi ${ }^{1 *}$, Irwan Mahakam Lesmono Aji ${ }^{1}$, dan Dwi Sukma Rini ${ }^{1}$ \\ ${ }^{1}$ Jurusan Kehutanan, Fakultas Pertanian, Universitas Mataram. \\ Jln. Majapahit No. 62, Mataram, NTB
}

\begin{abstract}
Bambusa blumeana BI. Ex. Schult. F. is a non-timber forest product used as building material by the people of Lombok. The utilization of bamboos leaves their branches as a waste that has not fully utilized. One way to take advantage of this waste is to use it as a raw material to make activated charcoal. The purpose of this study was to determine the effect of variations activation temperature, the concentration of phosphoric acid $\left(\mathrm{H}_{3} \mathrm{PO}_{4}\right)$, as well as interactions between variations of the activation temperature and the concentration of phosphoric acid $\left(\mathrm{H}_{3} \mathrm{PO}_{4}\right)$ on the quality of activated charcoal of $\mathrm{B}$. blumeana branch. This study employed a factorial completely randomized design $(R A L)$ with two (2) factors. The first factor $(A)$ was activation temperature i.e. $600^{\circ} \mathrm{C}\left(A_{1}\right), 700^{\circ} \mathrm{C}\left(\mathrm{A}_{2}\right)$, and $800^{\circ} \mathrm{C}\left(\mathrm{A}_{3}\right)$, meanwhile the second factor $(B)$ used the concentration of phosphoric acid $\left(\mathrm{H}_{3} \mathrm{PO}_{4}\right)$, namely $10 \%\left(\mathrm{~B}_{1}\right)$ and $20 \%\left(\mathrm{~B}_{2}\right)$. The results showed variations in the activation temperature significantly affected the yield and iodine adsorption. Based on the results, the best treatment was obtained at a temperature of $700^{\circ} \mathrm{C}$ with an $\mathrm{H}_{3} \mathrm{PO}_{4}$ concentration of $10 \%\left(\mathrm{~A}_{2} \mathrm{~B}_{1}\right)$ with the yield value of $76.04 \%$, moisture content of $2.12 \%$, volatile matter content of $32.70 \%$, ash content of $8.15 \%$, fixed carbon content of $59.15 \%$, and sodium adsorption of $599.63 \mathrm{mg} / \mathrm{g}$.
\end{abstract}

Keywords: Bambusa blumeana, activated charcoal, activation, phosphoric acid

\begin{abstract}
ABSTRAK
Bambu duri (Bambusa blumeana BI. Ex. Schult. F.) merupakan hasil hutan bukan kayu yang dimanfaatkan sebagai bahan bangunan oleh masyarakat Lombok. Pemanfaatan bambu tersebut meninggalkan limbah cabang yang belum dimanfaatkan secara maksimal. Salah satu pemanfaatannya adalah menjadi arang aktif. Tujuan penelitian ini adalah untuk mengetahui pengaruh variasi suhu aktivasi, konsentrasi asam fosfat $\left(\mathrm{H}_{3} \mathrm{PO}_{4}\right)$, serta interaksi antara variasi suhu aktivasi dan konsentrasi asam fosfat $\left(\mathrm{H}_{3} \mathrm{PO}_{4}\right)$ terhadap karakteristik arang aktif cabang bambu duri (B. blumeana). Penelitian ini menggunakan Rancangan Acak Lengkap (RAL) faktorial dengan 2 faktor, faktor pertama (A) menggunakan suhu aktivasi yaitu $600^{\circ} \mathrm{C}\left(\mathrm{A}_{1}\right), 700^{\circ} \mathrm{C}\left(\mathrm{A}_{2}\right)$, dan $800^{\circ} \mathrm{C}\left(\mathrm{A}_{3}\right)$, sedangkan faktor kedua $(\mathrm{B})$ menggunakan konsentrasi asam fosfat $\left(\mathrm{H}_{3} \mathrm{PO}_{4}\right)$ yaitu $10 \%\left(B_{1}\right)$ dan $20 \%\left(B_{2}\right)$. Hasil penelitian ini menunjukkan bahwa variasi suhu aktivasi berpengaruh nyata terhadap nilai rendemen dan daya serap iod. Berdasarkan hasil pengujian, perlakuan terbaik diperoleh pada suhu $700^{\circ} \mathrm{C}$ dengan konsentrasi $\mathrm{H}_{3} \mathrm{PO}_{4} 10 \%\left(\mathrm{~A}_{2} \mathrm{~B}_{1}\right)$ yang menghasilkan nilai rendemen sebesar 76,04\%; kadar air 2,12\%; kadar zat terbang $32,70 \%$; kadar abu 8,15\%; kadar karbon terikat 59,15\%; dan daya serap iod 599,63 mg/g.
\end{abstract}

Kata kunci: Bambusa blumeana, arang aktif, aktivasi, asam fosfat

\begin{tabular}{|c|c|c|c|}
\hline \multicolumn{4}{|c|}{ Article Info } \\
\hline *Corresponding $A$ & Iuthor & : & turmiya.fada28@gmail.com (T.F. Adawi) \\
\hline Articel History & & & $\begin{array}{l}\text { Received } 22 \text { June 2020; received in revised from } 18 \text { February 2021; accepted } 23 \text { April 2021; Available } \\
\text { online since } 30 \text { April } 2021\end{array}$ \\
\hline How to cite this at & rticle & & $\begin{array}{l}\text { Adawi, T.F., Aji, I.M.L., \& Rini, D.S. (2021). Pengaruh Suhu Dan Konsentrasi Asam Fosfat }\left(\mathrm{H}_{3} \mathrm{PO}_{4}\right) \\
\text { Terhadap Kualitas Arang Aktif Cabang Bambu Duri (Bambusa blumeana Bi. Ex. Schult. F.). Jurnal } \\
\text { Penelitian Kehutanan Faloak, 5(1):62-73. DOI: http://doi.org/10.20886/ipkf.2021.5.1.62-73 }\end{array}$ \\
\hline Read Online & 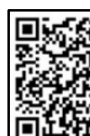 & 㫛 & C.JPKF-2021. Open access under CC BY-NC-SA license \\
\hline
\end{tabular}




\section{PENDAHULUAN}

Bambu merupakan salah satu Hasil Hutan Bukan Kayu (HHBK) yang banyak tumbuh di daerah dekat sungai dengan daur hidup yang relatif cepat, serta memiliki waktu panen 3-4 tahun (Arsad, 2015). Salah satu jenis bambu yang banyak tumbuh di NTB khususnya di Pulau Lombok yaitu bambu duri. Bambu duri merupakan bambu dengan ciri khas tersendiri, yaitu memiliki banyak duri yang terdapat pada cabangnya, dengan ukuran yang relatif besar dibandingkan dengan cabang bambu lainnya. Buluh bambu duri juga banyak dimanfaatkan oleh masyarakat sebagai bahan bangunan atau bahan baku dalam pembuatan berugak (bale-bale) di Desa Pengembur, Kecamatan Pujut, Kabupaten Lombok Tengah. Proses pengawetan biasa dilakukan sebelum bambu dimanfaatkan, dengan cara direndam pada larutan pengawet dari batang tembakau. Masyarakat pedesaan banyak meninggalkan cabang yang tidak dimanfaatkan pada saat bambu duri digunakan untuk bahan bangunan. Cabang-cabang tersebut jika dimanfaatkan hanya sebagai bahan bakar yang dapat menimbulkan polusi udara. Oleh sebab itu cabang bambu duri dapat dimanfaatkan sebagai bahan baku dalam pembuatan arang aktif untuk mengatasi masalah pencemaran udara.

Suheryanto (2012), menjelaskan bahwa arang bambu adalah material mikro-porus yang memiliki daya serap (adsorption) yang sangat bagus untuk area permukaan yang spesifik luasnya. Pembuatan arang aktif dapat dilakukan melalui proses aktivasi fisika, kimia, maupun kombinasi keduanya (Meisrilestari et al., 2013). Proses aktivasi fisika dapat dilakukan dengan pemanasan pada suhu tinggi tanpa kehadiran oksigen, sedangkan aktivasi kimia dapat dilakukan dengan perendaman arang menggunakan bahan kimia (aktivator)
(Surest et al., 2008). Menurut Surest et al., (2008), suhu yang baik pada pembuatan arang aktif menggunakan bahan baku tempurung kemiri adalah di atas $700^{\circ} \mathrm{C}$. Harsusanti (2018) menggunakan bahan baku dari ampas tebu, dan penelitian Jamilatun \& Setyawan (2014) menggunakan bahan baku tempurung kelapa, menunjukkan bahwa kualitas arang aktif terbaik menggunakan aktivasi fisika yang dihasilkan pada suhu $800^{\circ} \mathrm{C}$. Penelitian Sakmah (2017) yang menambahkan $\mathrm{H}_{3} \mathrm{PO}_{4}$ dengan konsentrasi $10 \%$ dalam pembuatan arang aktif kulit buah aren memiliki hasil terbaik pada suhu $650^{\circ} \mathrm{C}$. Purba et al., (2017) dalam penelitian arang aktif menggunakan ampas tebu menunjukkan bahwa kualitas terbaik diperoleh dari perlakuan perendaman $\mathrm{H}_{3} \mathrm{PO}_{4}$ dengan konsentrasi $20 \%$.

Pembuatan arang aktif menggunakan bambu duri (Bambusa blumeana BI. Ex Schult. F) masih sangat terbatas. Pemanfaatan cabang dari bambu duri dapat bermanfaat untuk mengurangi limbah dari bambu duri tersebut dan juga dapat mengurangi polusi akibat dari pembakaran, sehingga penelitian tentang pembuatan arang aktif menggunakan cabang bambu duri perlu untuk dilakukan. Tujuan penelitian ini adalah untuk mengetahui pengaruh variasi suhu aktivasi, konsentrasi asam fosfat $\left(\mathrm{H}_{3} \mathrm{PO}_{4}\right)$, serta interaksi antara variasi suhu aktivasi dan konsentrasi asam fosfat $\left(\mathrm{H}_{3} \mathrm{PO}_{4}\right)$ terhadap karakteristik arang aktif cabang bambu duri (B. blumeana BI. Ex Schult. F).

\section{METODE PENELITIAN}

Penelitian ini dilaksanakan pada bulan Maret-Juni 2019, yang bertempat di Laboratorium Teknologi Hasil Hutan, Program Studi Kehutanan dan Laboratorium Biologi dan Kimia Tanah, Fakultas Pertanian Universitas 
Mataram. Bahan yang digunakan adalah cabang bambu duri yang diperoleh dari Desa Pengembur, Kecamatan Pujut, Kabupaten Lombok Tengah, Provinsi Nusa Tenggara Barat, $\mathrm{H}_{3} \mathrm{PO}_{4}$ (teknis) dengan konsentrasi $10 \%$ dan $20 \%$, larutan iod $0,1 \mathrm{~N}$ sebagai bahan uji daya serap iod, natrium tio-sulfat $\left(\mathrm{Na}_{2} \mathrm{~S}_{2} \mathrm{O}_{3}\right)$ $0,1 \mathrm{~N}$ sebagai bahan titrasi, dan aquades sebagai air pembersih arang aktif pada proses aktivasi kimia. Alat yang digunakan adalah tungku drum kiln sebagai alat pengarangan/ karbonisasi, tanur/furnace, ayakan 80 mesh dan 100 mesh, lumpang porselin, oven, desikator, cawan porselin, $\mathrm{pH}$ meter, gelas ukur, pipet tetes, kertas saring, dan bak plastik.

\section{A. Pembuatan Arang Cabang Bambu Duri}

Cabang bambu duri dibelah dan dipotong sepanjang kurang lebih $5 \mathrm{~cm}$ dan dikeringkan di bawah sinar matahari dengan tujuan untuk mengurangi kandungan air pada bahan baku. Bahan baku yang sudah kering dikarbonisasi menggunakan drum kiln (Gambar 1). Arang yang dihasilkan setelah proses karbonisasi ditumbuk menggunakan lumpang porselin dan diayak menggunakan saringan 80 mesh.

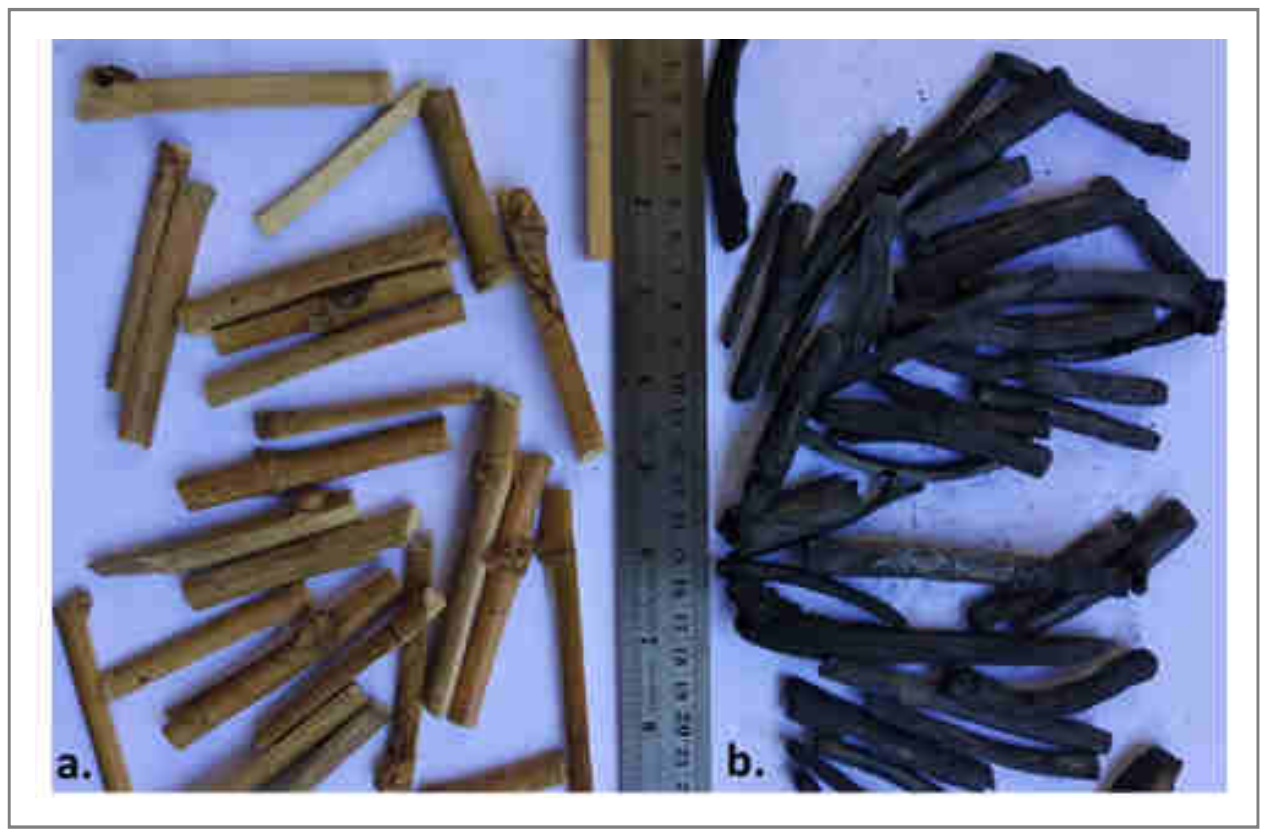

Gambar 1. Cabang Bambu Duri sebelum dikarbonisasi (a) dan setelah dikarbonisasi (b)

Figure 1. Branch of Bamboo Duri before carbonization (a) and after carbonization (b)

\section{B. Proses Aktivasi}

Arang berukuran 80 mesh diaktivasi secara kimia dengan perendaman di dalam $\mathrm{H}_{3} \mathrm{PO}_{4} \quad 10 \%$ dan $20 \%$ selama 24 jam (Manurung et al., 2017) kemudian dicuci bersih menggunakan aquades hingga $\mathrm{pH}$ netral dan dikeringkan. Selanjutnya arang diaktivasi pada suhu $600^{\circ} \mathrm{C}, 700^{\circ} \mathrm{C}$, dan $800^{\circ} \mathrm{C}$ masingmasing selama 60 menit (Rijali et al., 2015) menggunakan furnace (Gambar 2). 


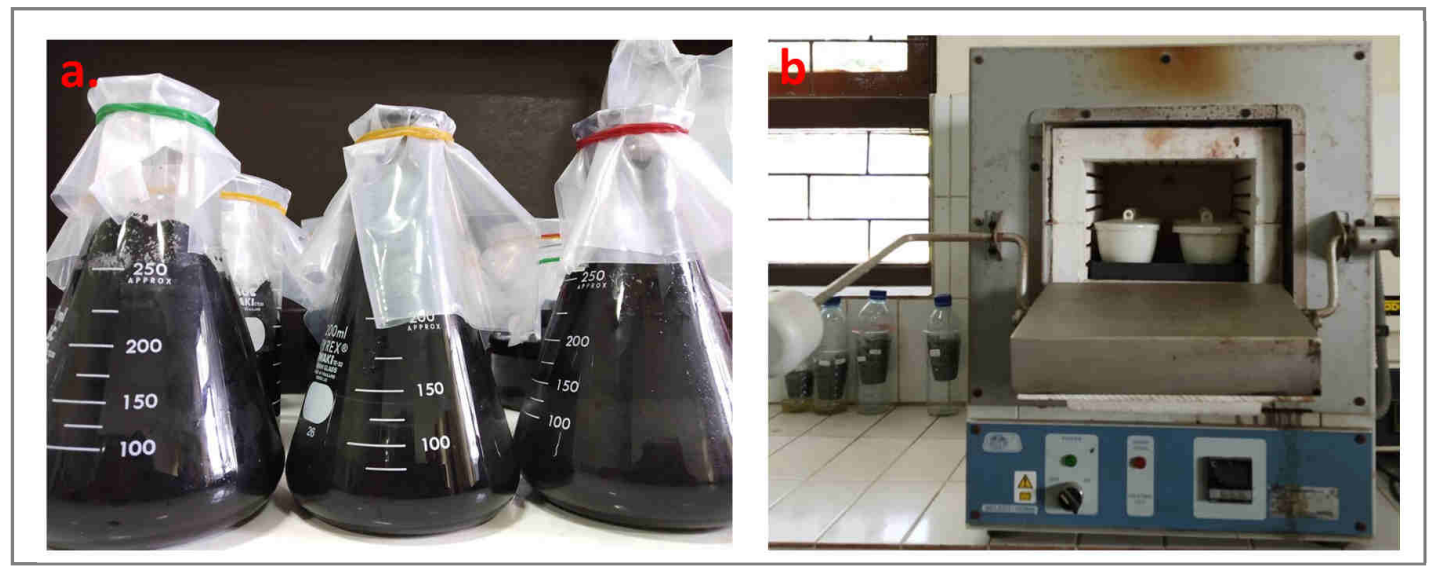

\section{Gambar 2. Proses aktivasi secara kimia (a) dan fisika menggunakan furnace (b)} Figure 2. Activation processes chemically (a) and physically using furnace (b)

\section{Pengamatan}

\section{Rendemen}

Penentuan nilai rendemen mengacu pada Pane \& Hamzah, (2018). Penetapan rendemen arang aktif dapat dihitung dengan membandingkan arang aktif yang dihasilkan dengan berat arang sebelum diaktivasi. Rendemen dihitung dengan rumus :

Rendemen $(\%)=\frac{\text { Berat arang sesudah diaktivasi }(\mathrm{g})}{\text { Berat arang sebelum diaktivasi }(\mathrm{g})} \times 100 \%$

\section{Kadar air}

Perhitungan nilai kadar air berdasarkan Manurung et al., (2019) mengacu pada Standar Nasional Indonesia (SNI) 06-3730-1995. Sampel uji arang sebanyak 1 gram dikeringkan dalam oven pada suhu $(103 \pm 2)^{\circ} \mathrm{C}$ sampai beratnya konstan, kemudian dimasukkan ke dalam desikator sampai bobotnya tetap dan ditentukan kadar airnya dalam persen (\%). Kadar air arang dihitung dengan rumus sebagai berikut :

$\operatorname{Kadar}$ Air $(\%)=\frac{\text { Berat sampel awal }(\mathrm{g})-\text { berat sampel kering tanur }(\mathrm{g})}{\text { Berat sampel awal }(\mathrm{g})} \times 100 \%$

\section{Kadar zat terbang}

Perhitungan nilai kadar zat terbang berdasarkan Lempang (2009) mengacu pada Standar Nasional Indonesia (SNI) 06-37301995). Sampel kering oven ditimbang sebanyak 1 gram dan dimasukkan ke dalam cawan porselin yang telah diketahui beratnya, dan selanjutnya dimasukkan ke dalam tanur listrik pada suhu $950^{\circ} \mathrm{C}$ selama 10 menit. Setelah didinginkan dalam desikator ditimbang sampai beratnya tetap.

Kadar zat terbang $(\%)=\frac{\text { Berat sampel kering oven }(\mathrm{g})-\text { berat sampel sisa }(\mathrm{g})}{\text { Berat sampel kering oven }(\mathrm{g})} \times 100 \%$ 


\section{Kadar abu}

Perhitungan nilai kadar abu berdasarkan Lempang (2009) mengacu pada Standar Nasional Indonesia (SNI) 06-3730-1995). Sampel uji kering oven ditimbang sebanyak 1 gram dan dimasukkan ke dalam cawan porselin

Kadar abu $(\%)=\frac{\text { Berat } a b u(g)}{\text { Berat kering oven }(g)} \times 100 \%$

\section{Kadar karbon terikat}

Perhitungan nilai kadar karbon terikat berdasarkan Lempang (2009) mengacu pada Standar Nasional Indonesia (SNI) 06-3730- yang sudah diketahui beratnya, kemudian dimasukkan ke dalam tanur listrik pada suhu $750^{\circ} \mathrm{C}$ selama 5 jam. Setelah didinginkan dalam desikator ditimbang sampai beratnya tetap. Besarnya kadar zat abu dapat dihitung dengan rumus :

Kadar karbon terikat $(\%)=100 \%-(\%$ kadar abu $+\%$ zat terbang $)$

1995). Kadar karbon terikat dihitung dengan cara pengurangan dari kadar abu dan zat terbangnya.

\section{Daya serap Iod}

Perhitungan nilai daya serap iod berdasarkan Jamilatun \& Setyawan (2014) mengacu pada Standar Nasional Indonesia (SNI) 06-3730-1995. Sampel yang telah kering oven ditimbang sebanyak $\pm 0,25 \mathrm{~g}$ dan dimasukkan ke dalam labu Erlenmeyer. Kemudian contoh uji tersebut diberi larutan yodium $25 \mathrm{ml}$, diaduk dengan menggunakan stirer selama \pm 15 menit. Larutan yang telah diaduk kemudian disaring dengan menggunakan kertas saring, dan hasilnya dipipet $10 \mathrm{ml}$ untuk titrasi menggunakan larutan thio-sulfat $\left(\mathrm{Na}_{2} \mathrm{~S}_{2} \mathrm{O}_{3}\right)$. Titrasi dilakukan hingga larutan sampel uji berubah warna menjadi bening. Besarnya daya serap arang aktif terhadap yodium dihitung dengan rumus:

Daya serap iod $(\mathrm{mg} / \mathrm{g})=\frac{\left(\frac{10-(\text { Molaritas Na2S2O3 }(0,1) \times \mathrm{ml} \text { Thio untuk titrasi })}{\text { Molaritas Yodium }(0,1002)}\right) \times 12,693 \times 2,5}{\text { Berat sampel awal }}$

\section{Analisis Data}

Penelitian disusun berdasarkan rancangan acak lengkap (RAL) dengan suhu, konsentrasi $\mathrm{H}_{3} \mathrm{PO}_{4}$, dan interaksi antara keduanya sebagai variabel independen. Untuk mengetahui pengaruh variabel-variabel tersebut terhadap parameter-parameter yang diuji, dilakukan analisis keragaman dengan tingkat kepercayaan 95\% ( $\alpha=0.05)$ (Sawyer, 2009). Jika nilai $F$ hitung lebih besar dari $F$ tabel $(P<0.05)$, maka dilakukan uji lanjut Tukey's $H S D$ dengan membandingkan selisih nilai parameter dan nilai HSD yang diperoleh untuk menentukan taraf perlakuan yang berbeda (Abdi dan William, 2010). Semua analisis statistika dalam penelitian ini dilakukan dengan software IBM SPSS.

\section{HASIL DAN PEMBAHASAN}

Nilai rata-rata setiap parameter untuk masing-masing perlakuan disajikan pada Tabel 1. Nilai rata-rata rendemen berkisar 
antara 72,66-76,86\%; kadar air berkisar antara 1,62\%-2,67\%; kadar zat terbang berkisar antara 32,70-36,01\%; kadar abu berkisar antara 7,92-11,58\%; kadar karbon terikat berkisar antara 53,81-59,15\%; dan daya serap iod berkisar antara 532,79-650,96 mg/g. Hasil analisis sidik ragam menunjukkan bahwa hanya faktor suhu yang berpengaruh nyata terhadap nilai rendemen dan daya serap iod arang aktif cabang bambu duri.

Tabel 1. Nilai rata-rata hasil pengujian arang aktif cabang bambu duri (B. blumeana) Table 1. Mean values of activated charcoal of B. blumeana branch characteristics

\begin{tabular}{|c|c|c|c|c|c|}
\hline \multirow{2}{*}{$\begin{array}{l}\text { Parameter } \\
\text { (Parameters) }\end{array}$} & \multicolumn{4}{|c|}{ Perlakuan (Treatment) } & \multirow{2}{*}{$\begin{array}{l}\text { Rata-rata } \\
\text { (Average) }\end{array}$} \\
\hline & & A1 & A2 & A3 & \\
\hline Rendemen (\%) & B1 & 75,52 & 76,04 & 73,30 & 74,95 \\
\hline \multirow[t]{2}{*}{ (Yield) } & B2 & 76,86 & 75,64 & 72,66 & 75,05 \\
\hline & Rata-rata & $76,19^{a}$ & $75,84^{\mathrm{a}}$ & $75,05^{b}$ & 75,00 \\
\hline Kadar Air (\%) & B1 & 2,40 & 2,12 & 1,78 & 2,10 \\
\hline \multirow[t]{2}{*}{ (Moisture content) } & B2 & 2,67 & 1,68 & 1,62 & 1,99 \\
\hline & Rata-rata & 2,53 & 1,90 & 1,70 & 2,04 \\
\hline Kadar Zat Terbang (\%) & B1 & 36,33 & 32,70 & 33,49 & 34,17 \\
\hline \multirow[t]{2}{*}{ (Volatile content) } & B2 & 36,01 & 33,19 & 34,61 & 34,61 \\
\hline & Rata-rata & 36,17 & 32,94 & 34,05 & 34,69 \\
\hline Kadar Abu (\%) & B1 & 7,92 & 8,15 & 8,54 & 8,20 \\
\hline \multirow[t]{2}{*}{ (Ash content) } & B2 & 7,99 & 10,45 & 11,58 & 10,01 \\
\hline & Rata-rata & 7,96 & 9,30 & 10,06 & 9,11 \\
\hline \multirow{3}{*}{$\begin{array}{c}\text { Kadar Karbon Terikat (\%) } \\
\text { (Fixed carbon content) }\end{array}$} & B1 & 55,74 & 59,15 & 57,97 & 57,62 \\
\hline & B2 & 56,00 & 56,36 & 53,81 & 55,39 \\
\hline & Rata-rata & 55,87 & 57,75 & 55,86 & 56,50 \\
\hline \multirow{3}{*}{$\begin{array}{c}\text { Daya Serap Iod (mg/g) } \\
\text { (Sodium adsorption) }\end{array}$} & B1 & 554,78 & 559,63 & 616,22 & 590,21 \\
\hline & B2 & 532,79 & 551,16 & 650,96 & 578,30 \\
\hline & Rata-rata & $543,78^{\mathrm{a}}$ & $575,40^{\mathrm{ab}}$ & $633,59^{b}$ & 584,26 \\
\hline
\end{tabular}

Keterangan (Remarks): A: Suhu aktivasi (Activation temperature), B: Konsentrasi asam fosfat (Concentration of phosphoric acid), AB: Interaksi (Interaction), a,b,ab: berbeda nyata (significant).

Tabel 2 menyajikan nilai perbandingan karakteristik arang aktif cabang bambu duri (B. blumeana BI. Ex. Schult. F.) dan SNI 063730-1995. Berdasarkan Tabel 2, hanya nilai kadar air dan kadar abu yang memenuhi setandar SNI, sementara parameter yang lain masih memiliki nilai di bawah atau di atas ambang batas SNI. 
Tabel 2. Perbandingan nilai rata-rata setiap parameter dengan Standar Nasional Indonesia (SNI 06-3730-1995)

Table 2. Comparation of the mean values of each properties with Indonesian Nnational Standard

\begin{tabular}{|c|c|c|c|c|c|c|c|c|}
\hline \multirow{2}{*}{$\begin{array}{l}\text { Parameter } \\
\text { (Parameters) }\end{array}$} & \multirow{2}{*}{$\begin{array}{l}\text { SNI } \\
(S N I)\end{array}$} & \multicolumn{6}{|c|}{ Perlakuan (Treatment) } & \multirow{2}{*}{$\begin{array}{l}\text { Signifikansi } \\
\text { (Significancy) }\end{array}$} \\
\hline & & $\mathbf{A}_{1} \mathbf{B}_{1}$ & $\mathbf{A}_{1} \mathbf{B}_{2}$ & $\mathbf{A}_{2} \mathbf{B}_{1}$ & $\mathbf{A}_{2} \mathbf{B}_{2}$ & $\mathbf{A}_{3} \mathbf{B}_{1}$ & $\mathbf{A}_{3} \mathbf{B}_{2}$ & \\
\hline Rendemen (\%) & - & 75,52 & 76,86 & 76,04 & 75,64 & 73,30 & 72,66 & 0,420 \\
\hline $\begin{array}{c}(\text { Yield }) \\
\text { Kadar Air }(\%) \\
\text { (Moisture content) }\end{array}$ & Maks 15 & $2,40^{*}$ & $2,67 *$ & $2,12 *$ & $1,68 *$ & $1,78^{*}$ & $1,62 *$ & 0,550 \\
\hline $\begin{array}{l}\text { Kadar Zat Terbang }(\%) \\
\quad(\text { Volatile content })\end{array}$ & Maks 25 & 36,33 & 36,01 & 32,70 & 33,19 & 33,49 & 34,61 & 0,976 \\
\hline $\begin{array}{l}\text { Kadar Abu }(\%) \\
(\text { Ash content })\end{array}$ & Maks 10 & $7,92^{*}$ & $7,99 *$ & $8,15^{*}$ & 10,45 & $8,54^{*}$ & 11,58 & 0,427 \\
\hline $\begin{array}{c}\text { Kadar Karbon Terikat }(\%) \\
\text { (Fixed carbon content })\end{array}$ & Min 65 & 55,74 & 56,00 & 59,15 & 56,36 & 57,97 & 53,81 & 0,698 \\
\hline $\begin{array}{c}\text { Daya Serap Iod (mg/g) } \\
\text { (Sodium adsorption) }\end{array}$ & Min 750 & 554,78 & 532,79 & 599,63 & 551,16 & 616,22 & 650,96 & 0,245 \\
\hline
\end{tabular}

\section{A. Rendemen}

Rendemen arang aktif menunjukkan jumlah arang aktif dalam setiap gram arang aktif yang digunakan berdasarkan pada berat awal sebelum aktivasi arang dan berat setelah proses aktivasi selesai (Maulana et al., 2017). Berdasarkan Tabel 1, penambahan konsentrasi $\mathrm{H}_{3} \mathrm{PO}_{4}$ dari $10 \%$ menjadi $20 \%$ menyebabkan nilai rata-rata rendemen arang aktif cabang bambu duri mengalami peningkatan sebesar $0,13 \%$. Peningkatan nilai rendemen akibat peningkatan konsentrasi $\mathrm{H}_{3} \mathrm{PO}_{4}$ juga terjadi pada penelitian Sahara et al., (2017) yang menggunakan bahan baku kulit durian. Pada penelitian tersebut rendemen mengalami peningkatan sebesar $1,4 \%$ pada penambahan $\mathrm{H}_{3} \mathrm{PO}_{4}$ konsentrasi $10 \%$ ke $20 \%$. Begitu pula halnya pada penelitian Sakmah (2017) yang membuat arang aktif dari kulit buah aren, peningkatan nilai rendemen sebesar 53,96\% terjadi ketika $\mathrm{H}_{3} \mathrm{PO}_{4}$ ditambahkan dengan konsentrasi $10 \%$. Peningkatan rendemen arang aktif pada setiap penambahan konsentrasi $\mathrm{H}_{3} \mathrm{PO}_{4}$ diduga karena $\mathrm{H}_{3} \mathrm{PO}_{4}$ dapat berfungsi sebagai pelindung arang dari suhu yang tinggi. Hal ini sesuai dengan Wibowo et al. (2010) yang menyatakan bahwa penambahan aktivator dapat melindungi arang dari suhu tinggi dengan memperlambat laju reaksi pada proses oksidasi, sehingga rendemen yang dihasilkan cenderung meningkat.

Berbeda halnya dengan nilai rata-rata pada peningkatan suhu aktivasi, semakin tinggi suhu aktivasi yang digunakan menyebabkan nilai rendemen semakin rendah. Menurut Lempang (2009), peningkatan suhu aktivasi dapat menurunkan nilai rendemen karena terjadi peningkatan reaksi di dalam retort yang dapat meningkatkan degradasi pada arang, sehingga rendemen yang dihasilkan juga berkurang.

Hasil analisis keragaman menunjukkan bahwa hanya faktor suhu yang berpengaruh nyata terhadap nilai rendemen arang aktif cabang bambu duri. Hasil uji lanjut menggunakan Tukey's HSD menunjukkan bahwa suhu $600^{\circ} \mathrm{C}$ $\left(\mathrm{A}_{1}\right)$ tidak berbeda nyata dengan suhu $700^{\circ} \mathrm{C}$ $\left(A_{2}\right)$, namun perbedaan terjadi ketika suhu 
dinaikkan menjadi $800^{\circ} \mathrm{C}\left(\mathrm{A}_{3}\right)$ yang ditandai dengan notasi yang berbeda (Tabel 1). Penurunan rendemen secara signifikan pada suhu di atas $700^{\circ} \mathrm{C}$ dapat terjadi karena masih meningkatnya laju reaksi antara karbon dan gas-gas di dalam furnace serta semakin banyaknya jumlah senyawa kadar zat mudah menguap (volatile content) yang terlepas (Ramdja et al., 2008).

\section{B. Kadar Air}

Penentuan kadar air bertujuan untuk mengetahui sifat higroskopis pada arang aktif (Sahara et al., 2017). Nilai kadar air arang aktif cabang bambu duri secara keseluruhan memenuhi standar mutu arang aktif menurut SNI No. 063730-1995 (Tabel 2), yaitu maksimal 15\%. Berdasarkan hasil penelitian (Tabel 1), semakin tinggi konsentrasi asam fosfat $\left(\mathrm{H}_{3} \mathrm{PO}_{4}\right)$ yang digunakan, nilai rata-rata kadar air arang aktif cabang bambu duri cenderung menurun. Hasil penelitian Pane \& Hamzah (2018) juga menunjukkan kecenderungan yang sama yaitu kadar air arang aktif kulit buah durian menurun sebesar 58,67\% seiring dengan penambahan konsentrasi $\mathrm{H}_{3} \mathrm{PO}_{4}$ dari $10 \%$ menjadi $20 \%$. Semakin tinggi konsentrasi aktivator mengakibatkan permukaan arang aktif semakin luas, sehingga kandungan air yang ada dalam poripori karbon akan lepas (Sani, 2011). Penurunan kadar air hasil penelitian ini juga terjadi pada setiap peningkatan suhu mulai dari $600^{\circ} \mathrm{C}, 700^{\circ} \mathrm{C}$, hingga $800^{\circ} \mathrm{C}$. Tinggi rendahnya kadar air arang banyak dipengaruhi oleh sifat higroskopis dan porositas dari arang tersebut, selain itu lama penempatan arang pada tempat terbuka pada proses pendinginan juga dapat memengaruhi kadar air arang aktif (Lempang, 2009).

\section{Kadar Zat Terbang}

Kadar zat terbang merupakan kandungan senyawa yang mudah menguap selain air pada arang aktif (Pari et al., 2009).
Senyawa yang mudah menguap tersebut yaitu nitrogen dan sulfur yang akan menguap pada pemanasan di atas $900^{\circ} \mathrm{C}$ (Maulana et al., 2017). Nilai kadar zat terbang arang aktif cabang bambu duri (B. blumeana BI Ex Schult. F.) secara keseluruhan tidak memenuhi standar SNI No. 06-3730-1995 (Tabel 2), di mana nilai kadar zat terbang yang disyaratkan dalam SNI tersebut adalah maksimal $25 \%$.

Berdasarkan hasil penelitian (Tabel 1), penambahan konsentrasi $\mathrm{H}_{3} \mathrm{PO}_{4}$ pada penelitian ini secara keseluruhan cenderung meningkatkan nilai rata-rata kadar zat terbang. Namun tidak demikian pada parameter suhu $600^{\circ} \mathrm{C}$ justru menurunkan nilai kadar zat terbang dengan peningkatan konsentrasi $10 \%$ menjadi $20 \%$ sebesar $0,88 \%$. Pari et al. (2006) menyatakan bahwa tinggi rendahnya kadar zat terbang yang dihasilkan menunjukkan bahwa permukaan arang aktif masih ditutupi oleh senyawa non karbon sehingga memengaruhi kemampuan daya serapnya.

Nilai kadar zat terbang tertinggi terdapat pada arang yang diaktivasi menggunakan suhu $600^{\circ} \mathrm{C}$. Tingginya nilai kadar zat terbang yang dihasilkan pada suhu $600^{\circ} \mathrm{C}$ ini disebabkan karena masih terdapat senyawa hidrokarbon seperti $\mathrm{CO}_{2}, \mathrm{CO}, \mathrm{CH}_{4}$, dan gas $\mathrm{H}_{2}$ yang menempel pada permukaan arang aktif yang belum terurai secara sempurna pada suhu tersebut (Pari, 2000).

\section{Kadar Abu}

Kadar abu yang terdapat dalam arang aktif merupakan sisa mineral yang tertinggal pada proses karbonisasi (Pane \& Hamzah, 2018). Berdasarkan hasil penelitian (Tabel 1), semakin tinggi konsentrasi $\mathrm{H}_{3} \mathrm{PO}_{4}$ yang digunakan, kadar abu arang aktif cabang bambu duri juga semakin meningkat. Penelitian lain yang menggunakan $\mathrm{H}_{3} \mathrm{PO}_{4}$ sebagai aktivator, juga menunjukkan hasil yang sama, yaitu pada 
pembuatan arang aktif kulit durian mengalami peningkatan nilai kadar abu dari konsentrasi $\mathrm{H}_{3} \mathrm{PO}_{4} 10 \%$ ke $20 \%$ yaitu dengan nilai kadar abu $7,19 \%$ menjadi $9,31 \%$ dengan suhu aktivasi $800^{\circ} \mathrm{C}$. Pane \& Hamzah (2018) menjelaskan bahwa semakin tinggi penambahan asam fosfat menyebabkan semakin banyak pori arang aktif yang terbuka. Hal ini disebabkan proses pembentukan pori terjadi selama proses pembakaran bidang permukaan dari arang aktif yang menghasilkan abu, sehingga semakin banyak pori yang dihasilkan menyebabkan kadar abu yang dihasilkan juga semakin tinggi. Semakin tinggi kadar abu yang terdapat pada arang aktif menyebabkan kemampuan arang aktif dalam mengadsorbsi juga semakin rendah karena pori arang aktif tertutup oleh mineral seperti $\mathrm{K}, \mathrm{Na}, \mathrm{Ca}$, dan $\mathrm{Mg}$ yang menempel pada permukaan arang aktif (Pari et al., 2008).

Begitu pula halnya dengan suhu aktivasi yang digunakan, semakin tinggi suhu yang digunakan pada aktivasi fisika, menyebabkan nilai kadar zat abu semakin meningkat. Peningkatan nilai kadar zat abu ini disebabkan oleh reaksi oksidasi yang terjadi selama proses aktivasi berlangsung (Lempang, 2009). Namun demikian, nilai kadar zat abu arang aktif cabang bambu duri sebagian telah memenuhi standar SNI No. 06-3730-1995 (Tabel 2), karena memiliki nilai kurang dari $10 \%$, kecuali arang aktif pada kombinasi perlakuan $\mathrm{A}_{2} \mathrm{~B}_{2}$ dan $\mathrm{A}_{3} \mathrm{~B}_{2}$.

\section{E. Kadar Karbon Terikat}

Kadar karbon terikat merupakan jumlah karbon murni yang terdapat dalam arang (Maulana et al., 2017). Besar kecilnya kadar karbon terikat pada arang aktif yang dihasilkan dipengaruhi oleh kadar abu dan kadar zat mudah menguap (Ramdja et al., 2008). Nilai kadar karbon arang aktif cabang bambu duri secara keseluruhan tidak memenuhi standar SNI No. 06-3730-1995 (Tabel 2), di mana nilai kadar karbon terikat yang dikehendaki oleh SNI adalah minimal $65 \%$. Rendahnya nilai kadar karbon terikat arang aktif cabang bambu duri pada penelitian ini disebabkan oleh tingginya nilai kadar zat terbang yang dihasilkan hingga mencapai 36,33\%. Hal ini sesuai dengan pernyataan Maulana et al. (2017) yang menyatakan bahwa semakin tinggi kadar abu dan kadar zat mudah menguap, maka semakin rendah kandungan karbon murni pada arang aktif.

Nilai kadar karbon terikat juga dipengaruhi oleh kandungan selulosa pada bahan baku. Sebagaimana menurut Pane \& Hamzah (2018) yang menyatakan bahwa semakin tinggi kandungan selulosa suatu bahan baku karbon aktif maka semakin tinggi nilai karbon murni yang dihasilkan. Bambu duri memiliki kadar selulosa sebesar 47,81\% (Sutardi et al., 2015) dengan nilai rata-rata kadar karbon terikat sebesar 56,51\%, lebih rendah dibandingkan dengan kadar selulosa kulit buah durian pada penelitian Pane \& Hamzah (2018) yaitu sebesar 50-60\% dengan nilai kadar karbon terikat sebesar $89,56 \%$.

\section{F. Daya Serap Iod}

Penetapan daya serap arang aktif terhadap iod bertujuan untuk mengetahui kemampuan arang aktif dalam menyerap larutan berwarna atau kotoran (Maulana et al., 2017). Daya serap arang aktif terhadap iodine merupakan salah satu parameter yang dapat menunjukkan kualitas arang aktif. Sakmah (2017) menyatakan bahwa semakin tinggi kemampuan arang aktif dalam penyerapan, maka semakin tinggi pula kualitas arang aktif tersebut.

Nilai daya serap iod arang aktif cabang bambu duri secara keseluruhan tidak memenuhi standar SNI No. 06-3730-1995 (Tabel 2) yaitu minimal $750 \mathrm{mg} / \mathrm{g}$. Rendahnya nilai daya serap 
iod pada hasil penelitian ini disebabkan karena tingginya nilai kadar zat abu dan kadar zat menguap yang terkandung dalam arang aktif yang menyebabkan rendahnya nilai kadar karbon. Maulana et al. (2017) menjelaskan bahwa semakin sedikit nilai karbon yang dihasilkan maka semakin sedikit pori-pori yang terbentuk, sehingga mengakibatkan luas permukaan arang aktif juga kecil serta daya serap iod arang aktif menjadi rendah.

Hasil analisis keragaman menunjukkan bahwa hanya faktor suhu yang berpengaruh nyata terhadap nilai daya serap iod arang aktif cabang bambu duri. Hasil uji lanjut menggunakan Tukey's HSD menunjukkan bahwa pada suhu $600^{\circ} \mathrm{C}\left(\mathrm{A}_{1}\right)$ tidak berbeda nyata dengan suhu $700^{\circ} \mathrm{C}\left(\mathrm{A}_{2}\right)$, begitu pula pada suhu $700^{\circ} \mathrm{C}$ ke $800^{\circ} \mathrm{C}\left(\mathrm{A}_{3}\right)$ tidak berbeda nyata. Perbedaan yang nyata terjadi pada suhu $600^{\circ} \mathrm{C}$ $\left(\mathrm{A}_{1}\right)$ ke $800^{\circ} \mathrm{C}\left(\mathrm{A}_{3}\right)$ yang ditandai dengan notasi yang berbeda (Tabel 1).

Semakin tinggi nilai daya serap iod pada setiap kenaikan suhu aktivasi disebabkan karena suhu yang tinggi dapat membuka pori-pori arang aktif sehingga kemampuan arang aktif dalam menyerap suatu bahan juga meningkat. Hal ini sesuai dengan pernyataan Turmuzi \& Syaputra (2015), yang menyatakan bahwa semakin tinggi suhu yang digunakan maka daya serap terhadap iodin dan luas permukaan arang aktif yang dihasilkan semakin baik.

\section{KESIMPULAN}

Suhu aktivasi berpengaruh nyata terhadap nilai rendemen dan daya serap iod arang aktif cabang bambu duri (B. blumeana BI. Ex Schult. F.). Konsentrasi asam fosfat $\left(\mathrm{H}_{3} \mathrm{PO}_{4}\right)$ serta interaksi antara suhu dan konsentrasi asam fosfat $\left(\mathrm{H}_{3} \mathrm{PO}_{4}\right)$ tidak berpengaruh nyata terhadap karakteristik arang aktif cabang bambu. Perlakuan terbaik untuk pembuatan arang aktif bambu duri adalah dengan suhu $700^{\circ} \mathrm{C}$ dan konsentrasi $\mathrm{H}_{3} \mathrm{PO}_{4} 10 \%$ $\left(\mathrm{A}_{2} \mathrm{~B}_{1}\right)$.

\section{UCAPAN TERIMA KASIH}

Penulis ingin berterima kasih kepada Bpk. Muhammad Sultan, selaku Kepala Desa Pengembur, Kecamatan Pujut yang telah memberikan izin dan menunjukkan lokasi untuk pengambilan sampel bambu, Sdr. Dika Adiatna yang telah membantu pengambilan sampel di lapangan, dan Sdr. Lalu Amrian Hardi yang telah membantu kegiatan di laboratorium.

\section{KONTRIBUSI PENULIS}

Konsep penelitian, Turmiya Fathal Adawi dan Dwi Sukma Rini; pengujian dan analisis data, Turmiya Fathal Adawi; metodologi, Turmiya Fathal Adawi; penulisan naskah, Turmiya Fathal Adawi, Irwan Mahakam Lesmono Aji, dan Dwi Sukma Rini. Semua penulis telah membaca dan menyetujui naskah yang dibuat.

\section{DAFTAR PUSTAKA}

Abdi, H., \& Williams, L. J. (2010). Tukey's honestly significant difference (HSD) test. Encyclopedia of research design, 3(1), 1-5.

Arsad, E. (2015). Teknologi pengolahan dan manfaat bambu. Jurnal Riset Industri Hasil Hutan, 7(1),45-52.

Harsusanti. (2018). Karakteristik arang aktif ampas tebu (Sacharum Officinarum, Linn.) menggunakan aktivasi fisika (Skripsi Sarjana). Program Studi Kehutanan. Universitas Mataram, Mataram.

Irma, K.N., Wahyuni, N., \& Zahra, T.A. (2015). Adsorbsi fenol menggunakan adsorben karbon aktif dengan metode kolom. $J K K$, $4(1), 24-28$. 
Jamilatun, S., \& Setyawan, M. (2014). Pembuatan arang aktif dari tempurung kelapa dan aplikasinya untuk penjernihan asap cair. Jurnal Spektrum Industri, 12(1), 1-112.

Lempang, M. (2009). Sifat-sifat arang aktif tempurung kemiri dan aplikasinya sebagai komponen media tumbuh pada tanaman melina (Gmelina arborea Roxb.) (Tesis Master). Sekolah Pascasarjana. Institut Pertanian Bogor, Bogor.

Manurung, M., Sahara, E., \& Sihombing, S.P. (2019). Pembuatan dan karakterisasi arang aktif dari bambu apus (Gigantochloa apus) dengan aktifator $\mathrm{H}_{3} \mathrm{PO}_{4}$. Jurnal Kimia, 13 (1),16-21.

Maulana, G.G.R., Agustina, L., \& Susi. (2017). Proses aktivasi arang aktif dari cangkang kemiri (Aleurites moluccana) dengan variasi jenis dan konsentrasi aktivator kimia. Jurnal Ziraa'ah, 42(3),247-256.

Meisrilestari, Y., Khomaini, R., \& Wijayanti, H. (2013). Pembuatan arang aktif dari cangkang kelapa sawit dengan aktivasi secara fisika, kimia, dan fisika-kimia. Konversi, (21),47-51.

Pane, G.C., \& Hamzah, F. (2018). Pemanfaatan kulit buah durian pada pembuatan arang aktif dengan metode aktivasi fisika-kimia menggunakan asam fosfat. Jurnal JOM Faperta 5, 1-14.

Pari, G. (2000). Pembuatan arang aktif dari batubara. Buletin Penelitian Hasil Hutan, 17(4), 220-230.

Pari, G., Hendra, D., \& Pasaribu, R.A. (2006). Pengaruh lama waktu aktivasi dan konsentrasi asam fosfat terhadap mutu arang aktif kulit kayu Acacia mangium. Jurnal Penelitian Hasil Hutan, 24(1), 3346.

Pari, G., Widayati, D.T., \& Yoshida, M. (2009). Mutu arang aktif dari serbuk gergaji kayu. Jurnal Penelitian Hasil Hutan, 27(4),381398.
Purba, A.G., Hamzah, F., \& Restuhadi, F. (2017). Pemanfaatan arang aktif dari ampas tebu (Saccharum officinarum) pada pemurnian minyak goreng bekas dengan metode aktivasi kimia-fisika menggunakan $\mathrm{H}_{3} \mathrm{PO}_{4}$. Jurnal JOM Faperta, 4(1),1-15.

Ramdja, A.F., Halim, M., \& Handi, J. (2008). Pembuatan karbon aktif dari pelepah kelapa (Cocus nucifera). Jurnal Teknik Kimia, 15(2),1-8.

Rijali, A., Malik, U., \& Zulkarnain. (2015). Pembuatan dan karakterisasi karbon aktif dari bambu betung dengan aktivasi menggunakan activating agent $\mathrm{H}_{2} \mathrm{O}$. JOM FMIPA, 2(1),102-107.

Sahara, E., Sulihngtyas. W.D., \& Mahardika, I.P.A.S. (2017). Pembuatan dan karakterisasi arang aktif dari batang tanaman gumitir (Tagates erecta) yang diaktivasi dengan $\mathrm{H}_{3} \mathrm{PO}_{4}$. Jurnal Kimia, 11(1),1-9.

Sakmah. (2017). Pengaruh penambahan asam fosfat (h3po 4 ) dan variasi suhu aktivasi terhadap sifat arang aktif kulit buah aren (Arrenga pinnata Merr) (Skripsi Sarjana). Program Studi Kehutanan. Universitas Mataram, Mataram.

Sani. (2011). Pembuatan karbon aktif dari tanah gambut. Jurnal Teknik Kimia, 5(2),400406.

Sawyer, S. F. (2009). Analysis of variance: the fundamental concepts. Journal of Manual \& Manipulative Therapy, 17(2), 27E-38E.

Suheryanto, D. (2012). Penelitian pembuatan arang bambu (bamboo charcoal) pada suhu rendah untuk produk kerajinan. Jurnal Dinamika Kerajinan dan Batik, 32(2),33-47.

Surest, A.H., Kasih, J.A.F., \& Wisanti, A. (2008). Pengaruh suhu, konsentrasi zat aktivator dan waktu aktivasi terhadap daya serap karbon aktif dari tempurung kemiri. Jurnal Teknik Kimia, 15(2),17-22. 
Sutardi, S.R., Najib, N., Jasni, M.M., Sulastianingsih, I.M., Komaryati, S., Suprapti, S., Abdurrahman, \& Basri E. (2015). Seri paket iptek informasi sifat dasar dan kemungkinan penggunaan 10 jenis bambu. Pusat Penelitian dan Pengembangan Hasil Hutan Badan Penelitian, Pengembangan, dan Inovasi Kementerian Lingkungan Hidup dan Kehutanan. Bogor: IPB Press.

Turmuzi, M. \& Syaputra, A. (2015). Pengaruh suhu dalam pembuatan karbon aktif dari kulit salak (Salacca edulis) dengan impregnasi asam fosfat $\left(\mathrm{H}_{3} \mathrm{PO}_{4}\right)$. Jurnal Teknik Kimia USU, 4(1),42-46.

Wibowo, S., Syafii W., Pari G. (2010). Karakteristik arang aktif tempurung biji nyamplung (Calophyllum inophyllum Linn). Jurnal Penelitian Hasil Hutan, 28(1),43-54. 